\title{
Interaction of the Ustilago maydis KP6 killer toxin with sensitive cells
}

\author{
Idit Ginzberg and Yigal Koltin
}

Department of Molecular Microbiology and Biotechnology, G. S. Wise Faculty of Life Sciences, TelAviv University, Ramat-Aviv 69978, Tel-Aviv, Israel
Author for correspondence: Yigal Koltin. Tel: +972 3 6409988. Fax: +97236415135. e-mail: YIGAL@CCSG.TAU.AC.IL

\begin{abstract}
The dsRNA viruses of the corn pathogen Ustilago maydis encode toxins that affect sensitive strains of the same species and related species. The KP6 toxin encoded by the P6 virus subtype is a binary toxin, consisting of two polypeptides, $\alpha(8.6 \mathrm{kDa})$ and $\beta(9.1 \mathrm{kDa})$ with no covalent or hydrogen bonds between them. In this study the effect of each polypeptide was tested on sensitive and resistant cells and spheroplasts of $U$. maydis. The results indicate that both polypeptides bind to intact cells from sensitive and resistant strains; however, only spheroplasts of sensitive strains are affected by the toxin and both $\alpha$ and $\beta$ are necessary to affect the spheroplasts.
\end{abstract}

Keywords: Ustilago maydis, dsRNA virus toxins, killer toxins

\section{INTRODUCTION}

Viruses have been detected in more than 100 fungal species. Among those characterized the vast majority are dsRNA viruses (Buck, 1986). In two systems, Saccharomyces cerevisiae and Ustilago maydis, the viruses encode a toxin that is secreted and is effective against sensitive cells of the same species and closely related species (Bussey, 1991; Koltin, 1988; Wickner, 1986). In U. maydis three different toxin specificities have been identified: KP1, KP4 and KP6. Each is associated with a different segmented dsRNA virus subtype known as P1, P4 and P6, reviewed by Koltin (1988).

The KP6 toxin, encoded by the M2 segment of the P6 virus subtype, consists of two polypeptides, $\alpha(8.6 \mathrm{kDa})$ and $\beta(9 \cdot 1 \mathrm{kDa})$. The polypeptides are encoded by a single mRNA and the preprotoxin is processed to yield two polypeptides which are not covalently linked (Tao et al., 1990; Peery et al., 1987). Each of these polypeptides is secreted by different non-killer mutants (Koltin \& Kandel, 1978). The biological activity of the toxin can be reconstituted in vitro and, therefore, the interaction of each subunit with the cell can be studied. The activity of the two polypeptides appears to be necessary for killing, yet, the interaction seems to occur in a sequential manner with $\alpha$ initiating the toxic effect (Peery et al., 1987). Spheroplasts of sensitive cells were found to be insensitive to KP6 and only upon regeneration of the cell wall was sensitivity elicited, suggesting a role for the cell wall in the toxic effect (Steinlauf et al., 1988).

The mode of action of the toxin has never been determined. Previously it was suggested that KP6 acts as a nuclease (Levine et al., 1979). An in vitro nuclease activity was found to be associated with partially purified toxin. The nuclease activity was non-specific, affecting ssRNA, ss- and dsDNA. Only dsRNA did not appear to serve as a substrate.

The $S$. cerevisiae toxin $\mathrm{k} 1$ bears some similarity to the KP6 toxin. It consists of two subunits, $\alpha(9.5 \mathrm{kDa})$ and $\beta(9.0 \mathrm{kDa})$. However, these polypeptides are covalently linked by three disulfide bonds (Bostian et al., 1984). $\beta$ appears to serve as the recognition unit and $\alpha$ as the catalytic unit (Sturley et al., 1986). As shown by patch clamping using spheroplasts and liposomes, the yeast toxin $\mathrm{k} 1$ forms ion-channels in membranes of sensitive cells (Martinac et al., 1990). Two additional yeast toxins are known, $\mathrm{k} 2$ and $\mathrm{k} 28$. Whilst $\mathrm{k} 2$, like $\mathrm{k} 1$, binds to cell wall glucans and disrupts membrane functions, $k 28$ toxin binds to cell wall mannoprotein and causes inhibition of DNA synthesis (Schmitt \& Radler, 1987; Tipper \& Schmitt, 1991). The toxins of Pichia kluyveri (Kagan, 1983) and Torulopsis glabrata (Bussey \& Skipper, 1975) are also thought to act as channel formers. The killer character of Kluyveromyces lactis is distinct from the other known yeast killer systems as the protein toxin, which is encoded by a dsDNA plasmid, irreversibly arrests proliferation of sensitive Saccharomyces cerevisiae cells in the G1 phase of the cell cycle (Butler et al., 1991; Stark et al., 1990).

With further progress in purification and characterization of KP6 we re-examined its mode of action using HPLCpurified $\alpha$ and $\beta$ subunits. In addition, studies on the interaction of the polypeptides with whole cells and spheroplasts of sensitive and resistant strains were conducted. The results indicate that the purified toxin does not display nuclease activity and suggests that KP6 affects membrane integrity in sensitive cells. Both $\alpha$ and $\beta$ are 
essential for the lethal effect. Furthermore, we show that both subunits bind indiscriminately to the cell walls of resistant and sensitive cells, yet, membrane disintegration occurs only in sensitive spheroplasts. It is suggested that the spheroplasts contain a receptor for the toxin.

\section{METHODS}

Strains. The strains used were from the collection at Tel-Aviv University and most have been deposited also in the American Type Culture Collection (Rockville, MD, USA) (Table 1). Strain 75-1U1, lacking the viral dsRNA segments that are associated with toxin expression, was obtained spontaneously from strain 75-1 that contains the P6 virus. The non-killer mutant $75-1 \mathrm{NK} 3$ was obtained spontaneously from the killer strain $75-1$. The mutant $75-1$ NK13 was obtained by cytoplasmic transfer of viruses from strain 3038 to $75-1 \mathrm{U} 1$ (Peery et al., 1987). The reconstituted toxin, obtained by combining the inactive polypeptides secreted by mutants 75-1NK3 and 75$1 \mathrm{NK} 13$, is as active as the native toxin secreted by the killer strain 75-1 (Peery et al., 1987).

Strain 18 is sensitive to all of the viral toxins of $U$. maydis. Therefore, this strain served as an indicator for toxin activity. Cells of this strain were used to study the effect of the toxin on whole cells and spheroplasts.

Growth medium and preparation of the toxin. Cells were grown in Ustilago minimal medium (UMM) (Holliday, 1961) buffered to $\mathrm{pH} 7.0$ with $50 \mathrm{mM}$ sodium phosphate buffer or in complete medium (YPD) containing $1 \%(\mathrm{w} / \mathrm{v})$ peptone, $1 \%$ $(\mathrm{w} / \mathrm{v})$ yeast extract and $2 \%(\mathrm{w} / \mathrm{v})$ glucose. Agar $(2 \%, \mathrm{w} / \mathrm{v})$ was added when needed. Cultures were grown at $27{ }^{\circ} \mathrm{C}$. For toxin preparation $5 \times 10^{3}$ cells $\mathrm{ml}^{-1}$ were inoculated into minimal medium and grown for $3 \mathrm{~d}$. The cells were harvested by centrifugation at $5860 \mathrm{~g}$ for $15 \mathrm{~min}$ at $4{ }^{\circ} \mathrm{C}$ and the supernatant was frozen. After thawing the supernatant was centrifuged ( $12000 \mathrm{~g}$ for $30 \mathrm{~min}$ ) to remove cell debris and polysaccharides, and dialysed against double-distilled water (Spectrapor dialysis tubing with a $M_{\mathrm{r}} 3500$ cut off). Each polypeptide, $\alpha$ or $\beta$, was prepared from one of the non-killer mutants $75-1$ NK13 or 751NK3, respectively. KP6 toxin produced by the wild-type (wt)

Table 1. Strains of Ustilago maydis

\begin{tabular}{|lllll|}
\hline Strain & $\begin{array}{c}\text { Killer } \\
\text { phenotype }\end{array}$ & $\begin{array}{c}\text { Virus } \\
\text { particle }\end{array}$ & $\begin{array}{c}\text { dsRNA } \\
\text { segment }\end{array}$ & $\begin{array}{c}\text { Nuclear } \\
\text { genotype* }\end{array}$ \\
\hline $75-1 \dagger$ & Killer & P6 & H1M2L & P6r(a2bK) \\
$75-1$ U1 & Non-killer & P6 & H1 & P6r(a2bK) \\
(ATCC 58963) & & & & \\
$75-1$ NK3 & Non-killer & P6 & H1M2L & P6r(a2bK) \\
(ATCC 58961) & & & & \\
$75-1 N K 13$ & Non-killer & P6 & H1M2L & P6r(a2bK) \\
(ATCC 58962) & & & & \\
H156-S & Non-killer & & & P6s(a2bB)inos \\
H156-R & Non-killer & & & P6r(a2bB)inos \\
18 & Non-killer & & & P6s(a2bG) \\
(ATCC 58959) $\ddagger$ & & & & \\
\hline
\end{tabular}

* From left to right: nuclear gene for resistance, mating type (in parentheses) and auxotrophic markers.

† Derived from ATCC 32356.

$\ddagger$ The universal sensitive tester strain. strain 75-1 contains equimolar amounts of $\alpha$ and $\beta$. The relative concentration of $\alpha$ and $\beta$ secreted by the mutants and the wt strain is the same (determined by $18 \%$ SDS-PAGE). The toxin or its polypeptides were concentrated by lyophilization of the supernatant.

Purification of the toxin. The toxin was partially purified from minimal medium using an ion-exchange column (CM Sephadex C-25), followed by size separation (Sephadex G-50), as described by Peery et al. (1987).

HPLC purification of the toxin was performed with a VYDAC Reverse Phase C4 analytical column $(4.6 \mathrm{~mm} \times 25 \mathrm{~cm}, 5 \mu \mathrm{m}$ silica, $300 \AA$ average pore size). Partially purified toxin $(1.5 \mathrm{mg})$ was dissolved in $0.1 \%$ trifluoro acetic acid (TFA) (Pierce) in water and loaded on the column. After washing the column with $25 \mathrm{ml} 0 \cdot 1 \%$ TFA, the toxin was eluted with $0.1 \%$ TFA/acetonitrile (Baker) and lyophilized.

The activity of the toxin preparations was tested by a killing zone assay. Aliquots of the toxin were spotted on a lawn of sensitive strain 18 . The lawn was prepared as an overlay of $10 \mathrm{ml}$ complete medium with $1 \%$ agar containing $2 \times 10^{6}$ cells.

Preparation of spheroplasts. Cells of either sensitive or resistant strains were grown in $50 \mathrm{ml}$ YEPS $(2 \%, \mathrm{w} / \mathrm{v}$, Bacto peptone, $1 \%, \mathrm{w} / \mathrm{v}$, yeast extract, $2 \%, \mathrm{w} / \mathrm{v}$, sucrose) to a density of $1 \times 10^{7}$ cells $\mathrm{ml}^{-1}$. Cells were harvested by centrifugation, washed with SCS buffer $(20 \mathrm{mM}$ sodium citrate, $\mathrm{pH} 5.8,0.6 \mathrm{M}$ sucrose) and resuspended in $2 \mathrm{ml}$ Novozyme 234 solution (Novo Industries).

To remove proteolytic activity from the preparation of the Novozyme, bentonite (Merck) was added at a ratio of $1: 1$ in $3 \mathrm{ml}$ SCS buffer. The mixture was incubated for $4 \mathrm{~h}$ at room temperature, centrifuged and the supernatant was filtered through a $0 \cdot 45 \mu \mathrm{m}$ filter for sterilization. To obtain spheroplasts, cells were treated with the Novozyme solution for $50 \mathrm{~min}$ at $27^{\circ} \mathrm{C}$ with gentle shaking. Under these conditions $98 \%$ of the cells converted to spheroplasts. Prior to testing the interaction with the toxin, spheroplasts were washed twice with S'T buffer (10 mM Tris/ $\mathrm{HCl}, \mathrm{pH} 7 \cdot 5,0.6 \mathrm{M}$ sucrose) and resuspended in the same buffer to an $\mathrm{OD}_{660}$ of $1 \cdot 1$.

Spheroplasts of $S$. cerevisiae strains were prepared as described by Sherman et al. (1982).

Interaction of cells and spheroplasts with the toxin. The effect of the toxin on cells was determined by addition of concentrated supernatant from a toxin-producing strain to $2 \times 10^{5}$ cells ml $\mathrm{m}^{-1}$ in complete medium. To determine survival of the cells, samples were withdrawn periodically for viable count. To study the effect of $\alpha$ and $\beta$ on the cells, $2 \times 10^{5}$ cells ml ${ }^{-1}$ were incubated for $1 \mathrm{~h}$ at room temperature with concentrated culture supernatants from each mutant expressing either $\alpha$ or $\beta$. Subsequently cells were washed four times in $10 \mathrm{mM}$ sodium phosphate buffer $(\mathrm{pH} 7 \cdot 0)$ and resuspended in complete medium $\left(2 \times 10^{5}\right.$ cells $\left.\mathrm{ml}^{-1}\right)$ containing the complementary toxin component. Periodically cells were withdrawn and plated on YPD for viable count. The results were calculated as the percentage of survivors vs time of exposure to the complementary toxin component.

The effect of the toxin on spheroplasts was determined after addition of concentrated toxin or each of its components, $\alpha$ or $\beta$, to spheroplasts at a density of $\mathrm{OD}_{660}=1 \cdot 1$. The change in OD after exposure to the toxin was monitored by spectrophotometer.

To determine whether the toxin binds to specific cell wall polysaccharides, the cell wall of a sensitive strain (18) was fractionated to alkali-soluble (S-glucan) and alkali-insoluble (R- 
glucan) according to Wessels (1965). Toxin was incubated with each fraction and the killing activity retained in the supernatant after the incubation was tested by spotting it on a lawn of a sensitjve strain.

Test for nuclease activity in purified toxin. HPLC-purified $\alpha$, $\beta$ or a mixture of both were incubated with $200 \mathrm{ng}$ DNA of the circular plasmid, pUC13, for $1 \mathrm{~h}$ at $37^{\circ} \mathrm{C}$. The amount of each purified toxin component used in the reaction was adjusted so that a mixture of both subunits caused a killing zone with a diameter of $1 \mathrm{~cm}$ in a lawn of sensitive cells. The incubation buffer contained $25 \mathrm{mM}$ Tris/ $\mathrm{HCl}(\mathrm{pH} 7 \cdot 8$ ), $50 \mathrm{mM} \mathrm{NaCl}$, $10 \mathrm{mM} \mathrm{MgCl}_{2}, 100 \mu \mathrm{g} \mathrm{BSA} \mathrm{ml}{ }^{-1}$ and $2 \mathrm{mM} \beta$-mercaptoethanol. The DNA was characterized in a $1 \%$ agarose slab gel and stained with ethidium bromide $\left(1 \mu \mathrm{g} \mathrm{ml}^{-1}\right)$. The DNA was viewed with an ultra-violet transilluminator and photographed with a Polaroid camera (MP4).

RNase activity, associated with the toxin, was tested in a wheat germ translation reaction (Amersham) containing yeast total mRNA after addition of HPLC-purified $\alpha, \beta$ or both. Products of the translation reaction were separated by $18 \%$ SDS-PAGE and autoradiographed.

\section{RESULTS}

\section{Two phases in the interaction of the toxin with the cell}

Experiments were performed to determine whether binding of the toxin leads to immediate lethality or the interaction with the cell consists of two phases that can be separated, binding of the toxin to the cell followed by a lethal hit. The experiments were performed with a dose of toxin that caused $90 \%$ lethality in a culture with a cell density of $10^{5} \mathrm{ml}^{-1}$ after exposure to the toxin for $60 \mathrm{~min}$.

Cultures $\left(10^{5} \mathrm{ml}^{-1}\right)$ were incubated in YPD containing a dose of KP6 as specified above for periods of up to $60 \mathrm{~min}$. At various time intervals, samples were withdrawn from the toxin, washed and resuspended in the

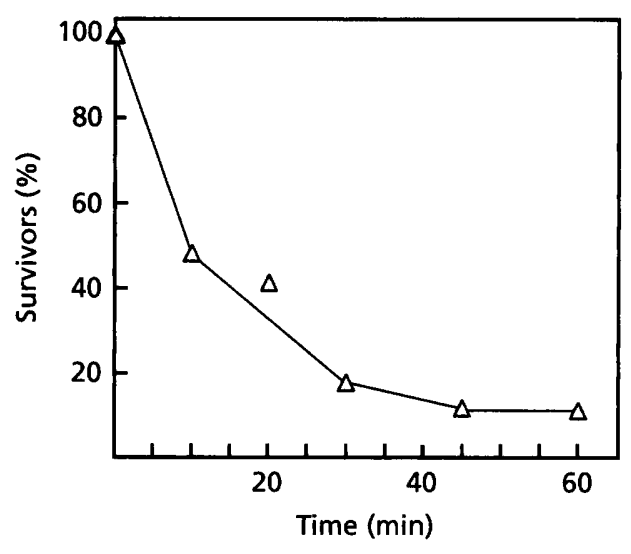

Fig. 1. Binding of KP6 to whole cells. Sensitive cells $\left(10^{5} \mathrm{ml}^{-1}\right)$ grown in YPD $\left(27^{\circ} \mathrm{C}\right)$ were exposed for $5 \mathrm{~min}$ to a dose of KP6 that caused $90 \%$ lethality within $60 \mathrm{~min}$. The cells were washed and resuspended $\left(10^{5} \mathrm{ml}^{-1}\right)$ in YPD medium without toxin. Samples were withdrawn for viable counts. Results are expressed as the percentage viability; $100 \%$ is the viability obtained by plating immediately after washing the cells of the free toxin. same volume of YPD without the toxin for $60 \mathrm{~min}$, which is less than a generation time of $U$. maydis, and then plated on YPD to determine the viability of the cells. The results obtained indicated that $5 \mathrm{~min}$ incubation with KP6 was sufficient for binding of toxin that can cause $90 \%$ lethality (Fig. 1). However, if the cells were exposed to KP6 for $5 \mathrm{~min}$, then washed and held in YPD for periods shorter than $60 \mathrm{~min}$, a higher survival was noticed among those cells plated early. These results may suggest that the toxic effect consists of two phases: a short binding phase and a toxic phase. The latter phase is complex and entails an interaction that is related to the physiological state of the cell (Peery, 1988). Plating the cells on solid medium may alter the state of the cells so that their sensitivity to the toxin is diminished and they may survive if they were not affected during the holding period in liquid. During the period required for the cells to resume cell division on solid medium the cells may recover from the damage and some of the toxin may be inactivated.

\section{Both $\alpha$ and $\beta$ can bind independently to the cells}

To determine whether both $\alpha$ and $\beta$ bind to the cells independently, sensitive cells $\left(2 \times 10^{5}\right)$ were suspended in $1 \mathrm{ml}$ YPD containing $\alpha$ or $\beta$ at a concentration that once combined will cause $90 \%$ lethality in a period of $1 \mathrm{~h}$. After incubation for $1 \mathrm{~h}$ at room temperature with either $\alpha$ or $\beta$, the cells were washed with $50 \mathrm{mM}$ sodium phosphate buffer ( $\mathrm{pH} \mathrm{7)}$ and resuspended in $1 \mathrm{ml}$ YPD containing the complementary component of the toxin. Samples were withdrawn and plated to determine survival in each culture. The initial incubation allowed maximum binding of each polypeptide to the cells. The exposure of the cells to the second polypeptide caused cell death and served as an indicator for the amount of polypeptide bound in the first incubation. The results shown in Fig. 2 indicate that both $\alpha$ and $\beta$ can bind to the cells but there are basic differences between the binding of each polypeptide.

Cells exposed initially to $\alpha$ and then to $\beta$, after removal of unbound $\alpha$, displayed similar kinetics of lethality to that obtained when cells were exposed to KP6. More than $90 \%$ lethality was obtained within $60 \mathrm{~min}$, suggesting that the binding sites for $\alpha$ were saturated during the $60 \mathrm{~min}$ incubation. However, in repeated experiments with cells initially exposed to $\beta$ and then to $\alpha$, after removal of unbound $\beta$, less cells died and only $55 \%$ of the cells died even after exposure to $\alpha$ for $60 \mathrm{~min}$. These results suggest that $\beta$ binds weakly to the cells and some can be removed by washing whilst $\alpha$ binds irreversibly.

To obtain an estimate of the minimal number of molecules that interact with a cell, based on the lethal effect induced, the same assays were repeated keeping one component of the toxin, either $\alpha$ or $\beta$ constant, and adding a series of dilutions of each of the complementary polypeptides (Fig. 3 ). The minimal number of molecules of $\alpha$ and $\beta$ was quantified by determination of the exact concentration of each component in $18 \%$ SDS-PAGE using lysozyme as a standard. Based on the known molecular mass of each polypeptide $(\alpha=8.6 \mathrm{kDa}$ and $\beta=9.1 \mathrm{kDa})$ and the cell density used in the experiment, the minimal number of 


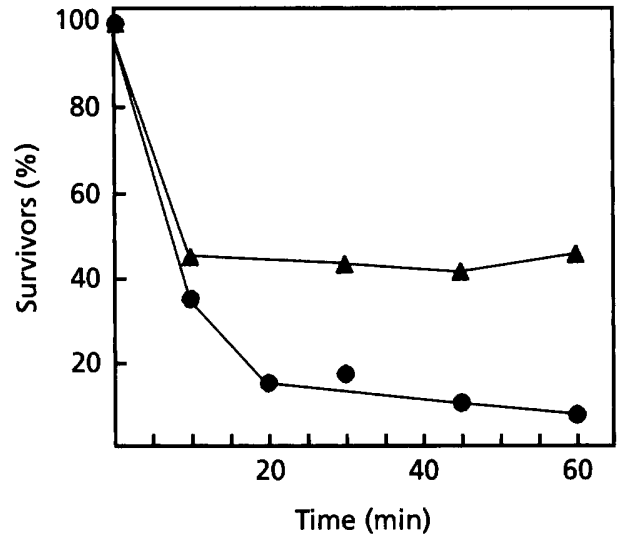

Fig. 2. Binding of $\alpha$ or $\beta$ to the cells. Sensitive cells $\left(2 \times 10^{5}\right)$ were treated with either $\alpha(0)$ or $\beta(\Delta)$ for $1 \mathrm{~h}$ at room temperature (the concentration of $\alpha$ and $\beta$ used was sufficient to cause $90 \%$ lethality when combined). Subsequently cells were washed with $50 \mathrm{mM}$ sodium phosphate buffer $(\mathrm{pH} \mathrm{7.0)}$ and resuspended in YPD with the complementary polypeptide. At various times samples were withdrawn for viable count. Results are expressed as the percentage viability of cells at different times following addition of the complementary polypeptide.

molecules of each component of the toxin that can elicit a lethal effect was calculated. The results obtained suggest that some $8.5 \times 10^{7}$ molecules of $\alpha$ and about $4.25 \times 10^{8}$ molecules of $\beta$ interact with each cell that dies. These results reflect the interaction with the intact cell and do not imply that more than a few molecules are necessary for the lethal effect. The numbers may reflect mostly binding to the cell walls. Furthermore, since each polypeptide, $\alpha$ and $\beta$, contains many cysteines and intramolecular S-S bonds, many molecules may bind to a cell, yet many may not be functional due to improper conformation. The results do indicate, however, that the interaction with the cell does not entail an equimolar amount of the two polypeptides but rather a $1: 5$ ratio of $\alpha$ to $\beta$. These relationships may reflect weaker binding of $\beta$ with the cell as noted above.

\section{The toxin binds to dead cells}

To test whether the binding of the toxin to the cells is energy-dependent and requires viable cells, an experiment was conducted with cells of the sensitive strain (18) and cells of a resistant strain (75-1) that were autoclaved. This treatment did not affect cell morphology as determined by microscopic observation and the cells appeared intact. The binding of the toxin was measured after $60 \mathrm{~min}$ incubation at room temperature. The cells were removed by centrifugation and $10 \mu \mathrm{l}$ of the supernatant were plated on a lawn of the sensitive strain (Fig. 4). The results indicate that both the resistant and the sensitive cells bound the toxin since no toxin was retained in the supernatant after incubation with the dead cells. Therefore, it appears that the binding to the cells, at least in the first phase, does not require energy. Furthermore, resistance to the toxin, known to be determined by a

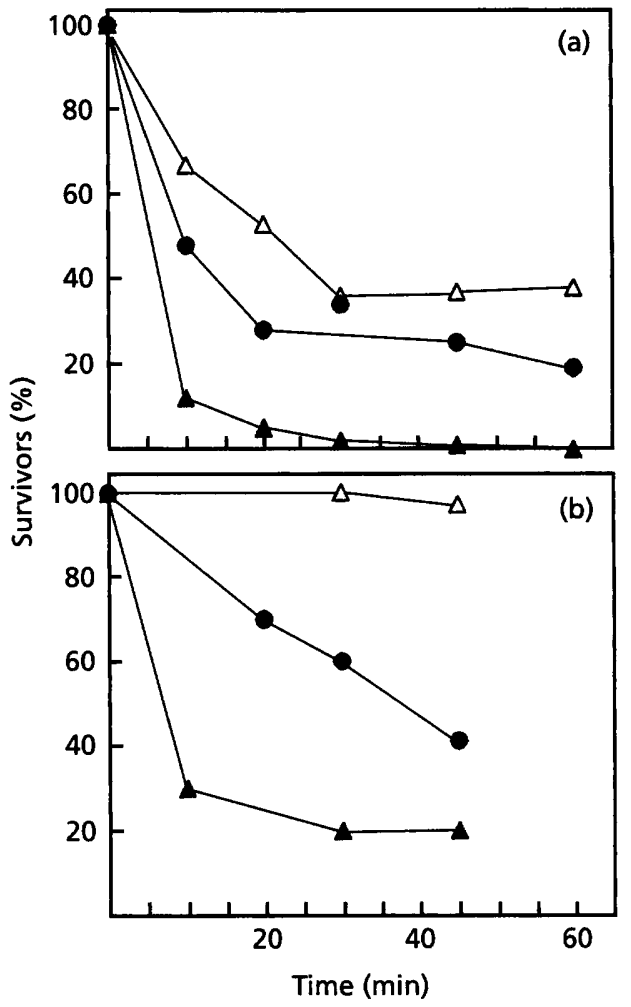

Fig. 3. The number of molecules of $\alpha$ and $\beta$ that interact with a cell. (a) Sensitive cells $\left(2 \times 10^{5} \mathrm{ml}^{-1}\right)$ were incubated with several dilutions of $\alpha$ (75-1NK13 supernatant) for $1 \mathrm{~h}$ at room temperature. Cells were washed and resuspended in YPD medium with $\beta$ and samples were withdrawn for viable count. Results are expressed as described in the legend to Fig. 2 . The dilutions were: $1: 20(\triangle) ; 1: 10(O) ; 1: 5(\Delta)$. (b) Sensitive cells $\left(2 \times 10^{5} \mathrm{ml}^{-1}\right)$ were incubated with a 1:10 dilution of 75-1 NK13 supernatant, which was found to be the minimal amount of $\alpha$ required for killing. After washing the cells they were resuspended in YPD with several dilutions of $\beta$ (75-1NK3 supernatant). Samples were withdrawn for viable count and the results are expressed as described in the legend to Fig. 2 . The dilutions were: $1: 5(\triangle) ; 1: 2.5(\Theta) ; 1: 1(\Delta)$.

recessive allele (Koltin, 1988) is not at the level of the cell wall.

\section{Indications that the toxin affects the membranes}

During the early phases of purification of the toxin, a nonspecific nuclease activity was reported as co-purifying with the toxin (Levine et al., 1979). The nucleolytic activity was re-examined using pUC13 (200 ng) with HPLC-purified $\alpha$ and $\beta$ of KP6, both individually and in combination, at levels that caused a $1 \mathrm{~cm}$ zone of inhibition when tested on a lawn of the sensitive strain 18 . After 60 min incubation at $37^{\circ} \mathrm{C}$ the DNA was tested by electrophoresis in a $1 \%$ agarose gel. No indications of DNase activity, endonuclease or exonuclease activity, or DNA nicking were found (Fig. 5). All three forms of the plasmid (cccDNA, relaxed and linear) were unaffected. Furthermore, the pattern of migration of the DNA provided no indication that the toxin acts as a DNAbinding protein that retards the migration of the DNA in 

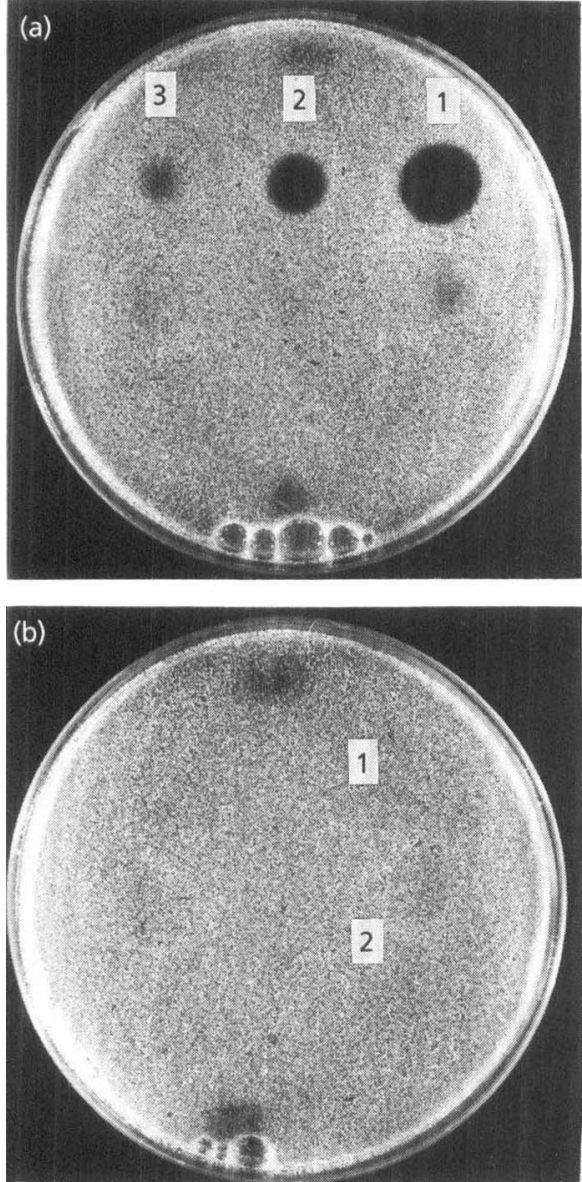

Fig. 4. Binding of KP6 to dead cells of a KP6-resistant strain (751) and a sensitive strain (18). KP6 was incubated with autoclaved dead cells of strains 75-1 and 18 for $1 \mathrm{~h}$ at room temperature. Cells were centrifuged and the supernatants were spotted on a lawn of sensitive cells. (a) KP6 (supernatant of 751) (1): KP6 diluted 1:2 (2) and 1:4 (3). (b) KP6 after incubation with dead cells of $18(1)$, or dead cells of 75-1 (2).

the agarose gel. Inhibition of translation in a wheat germ in vitro translation system was also tested with each of the polypeptides and with a reconstituted KP6 toxin but no change in translation efficiency was noticed. To verify that $\alpha$ and $\beta$ remained biologically active during these tests, samples were drawn from the DNA digestion mixture and the translation mixture, and tested by spotting on a lawn of strain 18. Zones of growth inhibition were detected, indicating that the toxin remained biologically active. The results of the tests indicate that the mode of action of the toxin is not as a nuclease, as suspected earlier, and that this activity must have resulted from an impurity of a molecular size similar to $\alpha$ and $\beta$ that was removed by the HPLC purification.

The effect of the toxin in various media and ionic conditions offered a new insight relating to its mode of action. The response of cells treated with KP6 is known to vary depending on the growth medium (Peery, 1988). Cells grown in UMM, which is enriched with salts, are less sensitive to the toxin than cells grown in complete

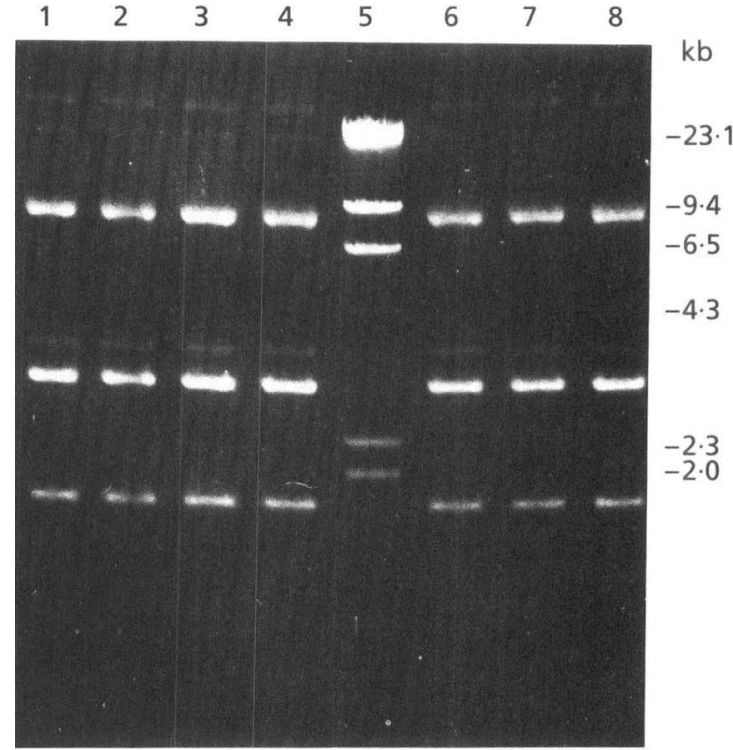

Fig. 5. Incubation of pUC13 with HPLC-purified $\alpha$ and $\beta$. pUC13 $(200 \mathrm{ng})$ was incubated with KP6 polypeptides. After $1 \mathrm{~h}$ incubation at $37^{\circ} \mathrm{C}$ samples were examined in a $1.0 \%$ agarose gel. (1) pUC13 $(200 \mathrm{ng}) ;(2,6)$ incubated with $\alpha ;(3,7)$ incubated with $\beta ;(4,8)$ incubated with $\alpha$ and $\beta$. Samples 6,7 and 8 were phenol-extracted before application on the gel.

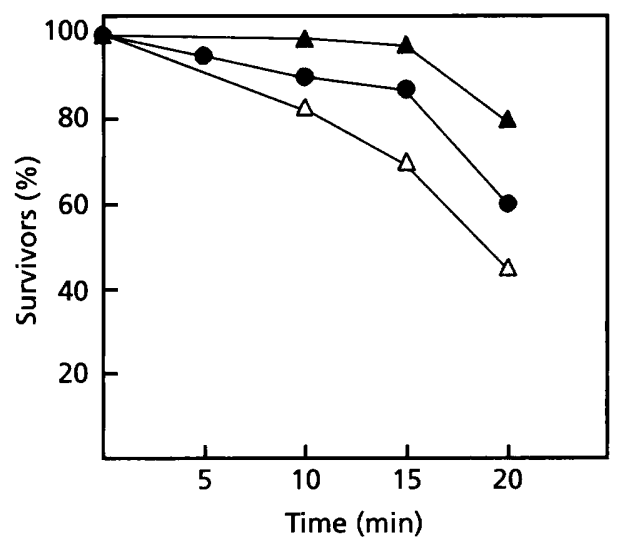

Fig. 6. Effects of $\mathrm{Ca}^{2+}$ and $\mathrm{K}^{+}$ions on cells treated with KP6. Sensitive cells $\left(2 \times 10^{5} \mathrm{ml}^{-1}\right)$ were incubated with KP6 at a concentration sufficient to cause $90 \%$ lethality. At various times samples were withdrawn and plated on YPD $(\triangle) ; Y P D+0.1 \mathrm{M}$ $\mathrm{CaCl}_{2}(\boldsymbol{\Delta})$ and $\mathrm{YPD}+0.05 \mathrm{M} \mathrm{KCl}(\mathbf{O})$. Results were expressed as the percentage viability of cells, $100 \%$ represents the initial number of cells prior to addition of toxin.

medium. Furthermore, treated cells can be rescued during a period of $15 \mathrm{~min}$ after exposure to the toxin if they are plated on complete medium containing $100 \mathrm{mM} \mathrm{CaCl}_{2}$ or $50 \mathrm{mM} \mathrm{KCl}$ (Fig. 6), treatments which have been shown to give protection against damage caused by agents which affect membranes (Kopecky et al., 1975; Middelbeek et al., 1980). After this period the damage to the cells is irreversible. 


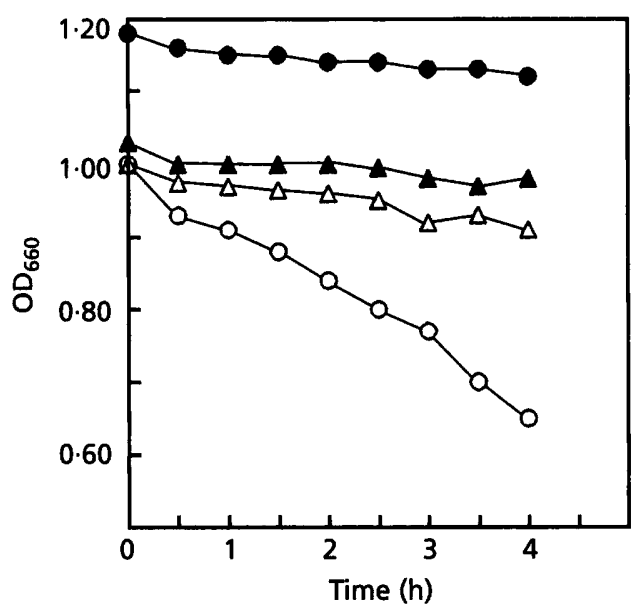

Fig. 7. Effect of KP6 on spheroplasts of a sensitive strain. Spheroplasts were treated with: KP6 (supernatant of 75-1) $(\triangle)$; KP6 concentrated threefold $(0)$; supernatant of a non-killer (75-1U1) concentrated threefold (O); no toxin (A). OD was measured at $660 \mathrm{~nm}$. The concentrated supernatant of 75-1U1 had a higher initial $O_{660}$ than KP6.

\section{The effect of KP6 on spheroplasts}

Spheroplasts of a sensitive strain maintained in an osmotic stabilizer $(0.6 \mathrm{M}$ sucrose) were treated with the toxin to determine whether the effect on the membranes can be determined visually. The OD of the spheroplast suspension was followed and a gradual decline in the OD was noticed as a function of time and as a dose-dependent response (Fig. 7). In microscopic observations lysis of spheroplasts was noticed. Spheroplasts of a sensitive strain incubated with threefold concentrated supernatant of the non-killer strain 75-1U1 remained unaffected (Fig. 7). In addition, spheroplasts of three resistant strains (75, 75-1U1 and H156R) were unaffected even after art overnight exposure to threefold concentrated culture supernatant of KP6. Since binding of the toxin by both sensitive and resistant cells appeared to be similar, yet the effect of the toxin on spheroplasts from resistant and sensitive cells is different, it appears that the membranes possess a component that determines the sensitivity of the cell, a component not found in a membrane of resistant cells. The binding to the cell walls occurs in both resistant and sensitive strains and, therefore, it is not directly related to the lethal effect.

The effect of each component, $\alpha$ and $\beta$, on the spheroplasts was tested to determine whether the different binding to the cell walls may reflect also a differential role in the interaction with the membrane. Since $\alpha$ binds well to intact cells and $\beta$ binds weakly under the same conditions, it is conceivable that each component plays a different role in the interaction with the cell and that once the cell walls are removed, one component can function without the other as shown for the yeast killer toxin (Sturley et al., 1986). However, the results obtained indicated that each component alone is ineffective. Only reconstituted toxin containing both $\alpha$ and $\beta$ caused membrane lysis as caused by the native KP6 toxin.
The specificity of the interaction at the level of the cell membranes was shown using spheroplasts from yeast strains of $S$. cerevisiae, sensitive or resistant to the $\mathrm{k} 1$ toxin encoded by the $S$. cerevisiae dsRNA virus $\mathrm{ScV} 1$. The effect on these spheroplasts was monitored by following the OD in the treated culture under osmotically stabilizing conditions and visually by phase contrast microscopy after addition of $0.1 \%$ SDS. The results indicate that spheroplasts of $S$. cerevisiae are not affected by KP6. In addition, spotting concentrated KP6 on a lawn of spheroplasts from a sensitive yeast strain had no discernible effect on these spheroplasts.

\section{DISCUSSION}

The results indicate that the KP6 toxin is not a nuclease as suggested previously (Levine et al., 1979). The results do not offer a direct answer defining the mode of action of KP6 but provide some indications on the complexity of the interaction of the two components, $\alpha$ and $\beta$, with the cell of $U$. maydis that culminates in the disruption of its cell membrane. The role of the cell wall in the process and the role of each component of the toxin can be inferred from the results.

The cell wall appears to play a role in the interaction of the toxin with the cells. This conclusion can be deduced from the fact that after removal of the cell walls by enzymic digestion, each of the toxin components still interacts with the spheroplasts but the activity of the toxin is some 30 -fold less effective. The decrease in activity can not be related to the degradation of membrane receptors since the decreased activity is detected also after removal of proteolytic activity from the hydrolytic enzymes. However, the cell wall may play a major role as a mediator for concentrating the binary toxin from an aqueous environment. Which of the cell wall constituents serve as ligands for the toxin is unclear. The viral-encoded toxins $\mathrm{k} 1$ and $\mathrm{k} 28$ of $S$. cerevisiae and the $K$. lactis DNA plasmidencoded toxin all bind to specific cell wall polysaccharides (Hutchins \& Bussey, 1983; Schmitt \& Radler, 1987; Stark et al., 1990). The Ustilago KP6 toxin binds neither to fractionated R-glucan nor to the S-glucan of the $U$. maydis cell walls (Ginzberg, 1990). Furthermore, the toxin does not bind to other defined polysaccharides such as laminarin, pustulan, lichenin and others (A. Finkler, personal communication). Yet, the toxin binds to viable and nonviable intact cells from resistant and sensitive strains. It appears that effective binding requires the intact cell wall or some combination of cell wall constituents. However, contrary to the findings in $S$. cerevisiae that relate the resistance to the toxin to the synthesis of a cell wall glucan (Al-Aidroos \& Bussey, 1978; Hutchins \& Bussey, 1983; Boone et al., 1990; Meaden et al., 1990), in Ustilago the resistance can not be attributed to the inability to bind to the cell wall and the resistance is displayed only in the response of the spheroplasts. Therefore, it appears that the site of action causing cell death is at the level of the membrane and not at the level of the cell wall.

A difference in the capacity to bind to the cell walls can be discerned between the KP6 polypeptides. The results 
suggest that $\alpha$ serves as the recognition component. Yet, recognition and binding to the Ustilago cell walls is not the only role of $\alpha$ since cells stripped of the walls cannot be killed by $\beta$ alone. The hydrophobic profile of $\alpha$ was found to be similar to that of cytotoxins with channel-forming activity (Tao et al., 1991). Furthermore, recent studies have shown that sensitive cells can tolerate the expression of $\alpha$ but not of $\beta$ (Finkler et al., 1992).

The precise mode of action of KP6 is still unknown but the study suggests that the effect is at the level of the membrane. The lysis of the spheroplasts suggests that the toxin is membrane active and the countereffect of various ions provides some indications that the effect is via channel formation as shown recently for $\mathrm{k} 1$ toxin of S. cerevisiae (Martinac et al., 1990). Efforts are currently directed to identify the receptors for KP6 and to test its direct effect on the cell membrane and in lipid bilayer systems.

\section{ACKNOWLEDGEMENTS}

The support of this research by the Foundation for Basic Research of the Israeli National Academy of Sciences and the US-Israel Binational Agricultural Research Foundation is acknowledged. We would like to thank Aviva Tamarkin and Dr Aliza Finkler for helpful discussions.

\section{REFERENCES}

Al-Aidroos, K. \& Bussey, H. (1978). Chromosomal mutants of Saccharomyces cerevisiae affecting the cell wall binding site for killer factor. Can J Microbiol 24, 228-237.

Boone, C., Sommer, S., Hensel, A. \& Bussey, H. (1990). Yeast KRE genes provide evidence for a pathway of cell wall a-glucan assembly. J Cell Biol 110, 1833-1843.

Bostian, K. A., Elliott, Q., Bussey, H., Burn, V., Smith, A. \& Tipper, D. (1984). Sequence of the pretoxin dsRNA gene of type I killer yeast: multiple processing events produce a two component toxin. Cell 36, 741-751.

Buck, K. W. (1986). Fungal virology - an overview. In Fungal Virology, pp. 1-84. Edited by K. W. Buck. Boca Raton: CRC Press.

Bussey, H. (1991). K1 killer toxin, a pore forming protein from yeast. Mol Microbiol 5, 2339-2343.

Bussey, H. \& Skipper, N. (1975). Membrane mediated killing of Saccharomyces cerevisiae by glycoproteins from Torulopsis glabrata. $J$ Bacteriol 124, 476-483.

Butler, A. R., Porter, M. \& Stark, M. J. R. (1991). Intracellular expression of Kluyveromyces lactis toxin $\gamma$ subunit mimics treatment with exogenous toxin and distinguishes two classes of toxinresistant mutants. Yeast 7, 617-625.

Finkler, A., Peery, T., Tao, J., Bruenn, J. \& Koltin, Y. (1992). Immunity and resistance to the KP6 toxin of Ustilago maydis. Mol \& Gen Genet 233, 395-403.

Ginzberg, I. (1990). The Ustilago maydis killer system: the organization of the toxin encoding genes and characterization of their products. $\mathrm{PhD}$ thesis, Tel Aviv University.

Holliday, R. (1961). The genetics of Ustilago maydis. Genet Res 2, 204-230.

Hutchins, K. \& Bussey, H. (1983). Cell wall receptor for yeast killer toxin: involvement of (1-6)- $\beta$-D-glucan. J Bacteriol 154, 161-169.
Kagan, B. L. (1983). Mode of action of yeast killer toxins: channel formation in lipid bilayer membranes. Nature 302, 709-711.

Koltin, Y. (1988). The killer system of Ustilago maydis: secreted polypeptides encoded by viruses. In Viruses of Fungi and Simple Eukaryotes, pp. 209-242. Edited by Y. Koltin \& M. Leibowitz. New York: Marcel Dekker.

Koltin, Y. \& Kandel, J. S. (1978). Killer phenomenon in Ustilago maydis: the organization of the viral genome. Genetics 88, 267-276.

Kopecky, A. L., Copeland, D. P. \& Lusk, J. E. (1975). Viability of Escherichia coli treated with colicin K. Proc Natl Acad Sci US A 72, 4631-4634.

Levine, R., Koltin, Y. \& Kandel, J. (1979). Nuclease activity is associated with the Ustilago maydis virus induced killer proteins. Nucleic Acids Res 6, 3717-3731.

Martinac, B., Zhu, H., Kubalski, A., Zhou, X., Culbertson, M., Bussey, H. \& Kung, C. (1990). Yeast k1 killer toxin forms ion channels in sensitive yeast spheroplasts and in artificial liposomes. Proc Natl Acad Sci US A 87, 6228-6232.

Meaden, P., Hill, K., Wagner, J., Slipetz, D., Sommer, S. S. \& Bussey, H. (1990). The yeast KRE5 gene encodes a probable endoplasmic reticulum protein required for (1-6)- $\beta$-D-glucan synthesis and normal cell growth. Mol Cell Biol 10, 3013-3019.

Middelbeek, E. J., van de Lar, H. H. A. M., Hermans, J. M. H., Stumm, C. \& Vogels, G. D. (1980). Physiological conditions affecting the sensitivity of Saccharomyces cerevisiae to a Pichia kluyveri killer toxin and energy requirements for toxin action. Antonie Leeuwenboek 46, 483-497.

Peery, T. (1988). Ustilago maydis virus encoded toxin: purification and characterization. $\mathrm{PhD}$ thesis, Tel Aviv University.

Peery, T., Shabat-Brand, T., Steinlauf, R., Koltin, Y. \& Bruenn, J. (1987). Virus-encoded toxin of Ustilago maydis: Two polypeptides are essential for activity. Mol Cell Biol 7, 470-477.

Schmitt, M. \& Radler, F. (1987). Mannoprotein of the yeast cell wall as primary receptor for the killer toxin of Saccharomyces cerevisiae strain 28. J Gen Microbiol 133, 3347-3354.

Sherman, F., Fink, G. R. \& Hicks, J. B. (1982). Methods in Yeast Genetics. Cold Spring Harbor, NY: Cold Spring Harbor Laboratory.

Stark, M. J. R., Boyd, A., Mileham, A. J. \& Romanos, M. A. (1990). The plasmid encoded killer system of Kluyveromyces lactis: a review. Yeast 6, 1-29.

Steinlauf, R., Peery, T., Koltin, Y. \& Bruenn, J. (1988). The Ustilago maydis virus-encoded toxin: effect of KP6 on sensitive cells and spheroplasts. Exp Mycol 12, 264-274.

Sturley, S. L., Elliot, Q., LeVitre, J., Tipper, D. J. \& Bostian, K. A. (1986). Mapping of functional domains within the Saccharomyces cerevisiae type 1 killer preprotoxin. EMBO J 5, 3381-3389.

Tao, J., Ginzberg, I., Banerjee, N., Held, W., Koltin, Y. \& Bruenn, J. (1990). Ustilago maydis KP6 killer toxin: structure, expression in Saccharomyces cerevisiae, and relationship to other cellular toxins. Mol Cell Biol 10, 1373-1381.

Tipper, D. J. \& Schmitt, M. J. (1991). Yeast dsRNA viruses: replication and killer phenotypes. Mol Microbiol 5, 2331-2338.

Wessels, J. G. H. (1965). Morphogenesis and biochemical processes in Scbizophyllum commune FR. Wentia 13, 1-113.

Wickner, R. B. (1986). Double-stranded RNA replication in yeast: the killer system. Annu Rev Biochem 55, 373-395.

Received 15 December 1992; revised 14 May 1993; accepted 24 September 1993. 